\title{
The Effect of Local Own Income and Transfer Funds on Fiscal Independence with Capital Expenditures as an Intervening Variable
}

\author{
Damita Damayanti ${ }^{1 *}$, Anwar Made ${ }^{2}$ Ati Retnasari ${ }^{3}$
}

\author{
${ }^{1,3}$ University Kanjuruhan Malang \\ ${ }^{2}$ Gajayana University of Malang \\ *Corresponding author. Email: damitad28@gmail.com.
}

\begin{abstract}
Fiscal independence is the goal of implementing regional autonomy. Through independence, the budget can regulate local government can give authority that has been given properly or not. The phenomenon that occurs in Indonesia according to the Minister of Finance Sri Mulyani, depending on the region on TKDD is still very high. This study aims to discuss and study regional transfers and funds towards financial independence with capital expenditure as an intervening variable. This type of research is causal comparative with quantitative research. The technique of collecting data in this study uses documentary techniques. The sample selection method uses census techniques. The samples used in this study were 28 districts and 8 cities in East Java Province. The analysis technique used in this study is path analysis (path analysis). Based on the results of the analysis, it can be concluded that the Regional Own Revenue (PAD) affects the fiscal independence, the transfer of funds affects the fiscal independence, regional original income is not related to capital expenditure, the transfer of funds is not to capital expenditure, capital expenditure is not appropriate to the independence of the PAD tax does not influences fiscal independence through capital expenditure, and transfers of funds do not agree to fiscal independence through capital expenditure.
\end{abstract}

Keywords: PAD, Transfer, Independence, Capital Expenditures

\section{INTRODUCTION}

Fiscal decentralization in Indonesia began to be implemented in line with the implementation of regional autonomy in the reform era, to be precise on January 1 , 2001. The implementation of fiscal decentralization is an opportunity for local governments to gain greater authority in regional financial management. The central government places high trust in the regions with the hope that the autonomous regions are able to independently carry out the authority that has been delegated to them. This strengthening of fiscal decentralization is marked by planning the allocation of transfers to regions and village funds (TKDD) in the 2019 Draft State Budget. Transfers from the central government to regional governments consist of the General Allocation Fund (DAU), the Special Allocation Fund (DAK), the Revenue Sharing Fund (DBH). ) Taxes and Natural Resources DBH, and Special Authority Funds. However, the expected conditions were inversely related to reality. This situation actually makes regions dependent on transfer funds from the central government.

According to Minister of Finance Sri Mulyani, regional dependence on TKDD is still very high. In addition, business records show that the regional average fiscal capacity index issued in 2018 was still very low. Only 4 or 11.7 percent of 34 provinces have a very high regional fiscal capacity index (KFD). Three provinces with a very high KFD index are in Java, namely DKI Jakarta, West Java and East Java. Meanwhile, those outside Java are only Papua Province. Even though data from the Ministry of Finance shows that East Java Province is in third place in the category of regions with a very high regional fiscal capacity index, this does not mean that all districts and cities in East Java Province have optimal regional fiscal independence. This can be recognized by one example of a region, namely Malang City. Mayor of Malang Sutiaji, who said that currently Malang City's regional dependence on transfers from the government in the form of General Allocation Funds (DAU) is still large. But gradually, this dependence is expected to decrease 
by encouraging local tax revenues, especially from the tourism and trade sectors. This year, Malang City's PAD revenue is estimated to reach Rp. 601 billion, with Rp. 501 billion coming from local tax revenue. With this amount of PAD revenue, Sutaji acknowledged that the Malang City Government's dependence on central government transfers was still high because the 2019 APBD volume was IDR 2.2 trillion. Therefore, the Malang City Government encourages regional fiscal independence by continuing to strive to increase revenue from PAD. With a large contribution of PAD, the Malang City Government is more flexible in spending the APBD for direct regional interests. For example, providing welfare to employees and other infrastructure development. (www.bisnis.com, 2019).

\section{LITERATURE REVIEW}

According to Siregar (2015: 31), PAD is revenue received by local governments from sources within their own territory which is collected based on regional regulations. According to Law no. 33 of 2004 concerning the Financial Balance between the Central Government and Regional Government, the objective of PAD is to give authority to local governments to fund the implementation of regional autonomy in accordance with regional potential as a manifestation of decentralization. PAD originates from local taxes, regional levies, proceeds from the management of separated regional assets, and other legal PAD. The results of Novalistia's research (2016) in the districts / cities of Central Java Province concluded that local taxes have a significant positive effect on the level of regional independence, local levies have a positive and insignificant effect on the level of regional independence, and other legal income has a significant positive effect on the level of independence. regional finance. However, the research of Orocomna, et al. (2017) concluded that taxes and levies partially have no effect on regional independence in Bintuni Bay Regency. Meanwhile, Lestari et al. (2016) concluded that PAD has a positive and significant impact on regional financial independence of Southeast Sulawesi Province. The definition of regional transfers in Herlinah (2017), transfers to regions are part of state spending in the context of implementing decentralization sourced from the APBN allocated to regions to reduce inequality in funding sources between the center and regions, reduce the gap in funding for government affairs between regions, reduce service gaps public between regions, funding the implementation of special autonomy and regional privileges. According to Law no. 23 of 2014 concerning Regional Government, central to regional government transfers consist of balancing funds, special autonomy funds, privileges funds, and village funds. Meanwhile, inter-regional transfers consist of revenue sharing and financial assistance. According to Law no. 33 of 2004 concerning Financial Balance between the Central Government and Regional Governments, the balance funds are funds sourced from APBN revenues allocated to regions to finance regional needs in the context of implementing decentralization. According to PP No.12 of 2019 concerning Regional Financial Management, balancing funds are divided into two types, namely general transfer funds and special transfer funds. General transfer funds are funds allocated in the APBN to regions to be used in accordance with regional authority to finance regional needs in the context of implementing decentralization, where general transfer funds consist of Profit Sharing Funds (DBH) and General Allocation Funds (DAU). Meanwhile, special transfer funds are funds allocated in the APBN to regions with the aim of helping to fund special activities both physical and nonphysical which are regional affairs, where the special transfer funds consist of Physical General Allocation Fund (DAK) and Non-Physical DAK.

Research by Nasution et al. (2018) reinforces this explanation that central government transfers have a significant effect on the regional financial independence of district / city governments in North Sumatra Province in 2011-2013. Other studies have partially tested each type of transfer fund from the central government. Research by Lestari et al. (2016) concluded that DAU has a significant and negative influence on the regional financial independence of Southeast Sulawesi Province. In contrast to Aisyah's research (2019) in Banyuwangi Regency which states that DAU has no effect on regional financial independence and DAK has a negative effect on regional inancial independence. Meanwhile, Kiak and Nuro's research (2018) concluded that the DAU and DAK had no significant effect on the level of regional financial independence in Banyuwangi Regency in 2012-2016. Novalistia's research (2016) states that $\mathrm{DBH}$ has a significant positive effect on the level of regional financial independence. However, the research of Purnima et al. (2015) concluded that DBH partially has no effect on fiscal independence in districts and cities of East Java Province. With regional independence, regions are given the authority to explore financial sources in their respective regions so that they are able to pay for their own regional expenditures, which consist of (routine) operational and capital expenditures. According to Siregar (2015: 167), capital expenditure is expenditure for the procurement of fixed assets. If capital expenditure increases, regional financial independence will also increase because larger capital expenditures are financed by local revenue, so the region can be said to be independent (Darwis, 2015).

Based on this explanation, regions should be able to independently manage their finances by maximizing $\mathrm{PAD}$ and as best as possible make use of transfer funds 
in the form of balanced funds with proportional spending allocations. However, when compared with existing phenomena, in the end the question arises, why is the level of regional fiscal dependence still so high? Is the transfer of funds to the regions insufficient? Shouldn't regions be more independent with the allocation of transfer funds from the central government? Or are the regions not ready to implement fiscal decentralization? From this phenomenon and research gap, this study re-examines the effect of PAD and Transfer Funds on Fiscal Independence through Capital Expenditures. The conceptual framework of this research is built from a theoretical study of regional fiscal (financial) independence and the relationship between variables. In addition, the conceptual framework of this research is also built on the results of studies on previous studies. Based on this explanation, the conceptual framework in this study can be described as follows:

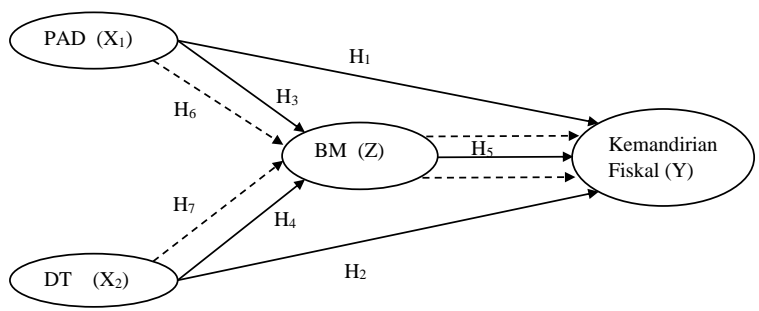

Information:

$\mathrm{X} 1$ = Regional Original Income (PAD)

$\mathrm{X} 2$ = Transfer Funds (DT)

$\mathrm{Y}=$ Fiscal Independence

$\mathrm{Z}=$ Capital Expenditure (BM)

$=$ Direct influence

$=$ Indirect influence

From this conceptual framework, the following research hypothesis can be formulated:

H1: PAD affects fiscal independence

$\mathrm{H} 2$ : Transfer funds have an effect on fiscal independence

H3: PAD affects capital expenditure

H4: Transfer funds affect capital expenditure

H5: Capital expenditure affects fiscal independence

H6: PAD affects fiscal independence through capital spending

H7: Transfer funds affect fiscal independence through capital expenditures.

\section{RESEARCH METHOD}

\subsection{Research Design}

The research design describes the type of research in accordance with the characteristics of the variables and research objectives. This type of research is comparative causal with a quantitative approach.

\subsection{Population and Sample}

The population in this study were all municipalities and regencies in the province of East Java which reported their APBD reports which included all funds, both from PAD and transfer funds in the form of balance funds. The sampling technique is also called the sampling technique. The sampling technique used in this study is the census technique, where all members of the population are used as samples because the research subjects are less than 100 (one hundred). Thus the samples in this study were 28 districts and 8 cities in East Java Province.

\subsection{Operational Definition of Variables Fiscal Independence $(Y)$}

The dependent variable in this study is Fiscal Independence. Fiscal independence is a reflection of the ability of local governments to finance their own government activities, including development and public services. Fiscal independence can be measured by the ratio of independence according to Halim (2007: 232) as follows:

\section{Independence Ratio $=$ \\ Regional Original Income \\ Central or Provincial Government Assistance and Loans}

\subsection{Operational Definition of Variables Regional Original Income (X1)}

Regional Original Income is regional revenue that comes from levies on regional sources itself according to applicable laws. Regional Original Income can be measured using the ratio of Regional Original Income to total income. According to the Directorate General of Fiscal Balance in the 2018 APBD Summary, the comparison of Regional Original Income to total revenue shows the level of independence of a region. Thus, the ratio measurement formula is:

\section{Regional Original Income Ratio = Regional Original Income \\ Total income}




\subsection{Operational Definition of Variables Transfer Funds (X2)}

The transfer funds referred to in this research are balancing funds. Balancing funds are a form of central government transfer to regions where these funds come from APBN revenues with the aim of helping finance regional needs in the context of implementing decentralization. The composition of the balancing fund is divided into 3 (three) main parts, namely the Revenue Sharing Fund (DBH), the General Allocation Fund (DAU), and the Special Allocation Fund (DAK). Balanced Funds can be measured using the ratio of Balanced Funds to total income. According to the Directorate General of Fiscal Balance in the 2018 APBD Summary, the ratio of balanced funds to regional revenues illustrates the level of regional dependence on funds from the center. The ratio calculation formula is:

Daper Ratio $=\frac{\text { Balancing Ratio }}{\text { Total income }} \times 100 \%$

\subsection{Operational Definition of Variables Capital Expenditure (Z)}

Capital expenditure is one type of regional expenditure for the acquisition of fixed assets and other assets that provide benefits for more than 1 (one) accounting period. According to the Directorate General of Fiscal Balance, capital expenditure can be measured using the capital expenditure ratio, where the portion of capital expenditure spent on total regional expenditure is in the context of providing services to the public. So that the capital expenditure ratio can be formulated as follows:

\section{Capital Expenditure Ratio $=$ \\ Portion of capital expenditure \\ Total regional expenditure}

\subsection{Path Analysis}

The structural equation developed in this study refers to (Yamin and Kurniawan, 2009) as follows:

$\mathrm{Z}=\mathrm{P} 1 \mathrm{X} 1+\mathrm{P} 2 \mathrm{X} 2$

$\mathrm{Y}=\mathrm{P} 3 \mathrm{X} 1+\mathrm{P} 4 \mathrm{X} 1+\mathrm{P} 5 \mathrm{Z}$

Information:

$$
\begin{array}{lr}
\text { Z } & \text { = Capital Expenditure } \\
\text { Y } & \text { = Fiscal Independence } \\
\mathrm{P} & =\text { Path Coefficient } \\
\mathrm{X} 1 & \text { = Regional Original Income (PAD) } \\
\mathrm{X} 2 & =\text { Transfer Funds (DT) }
\end{array}
$$

\section{RESULTS AND DISCUSSION}

\subsection{The Effect of Pad on Fiscal Independence}

Sig value. path $\mathrm{X} 1$ to $\mathrm{Y}$ (P1) of 0.000 smaller than the alpha value of 0.05 . This means that local revenue has an effect on fiscal independence. Thus, the first hypothesis which states that PAD affects fiscal independence can be accepted.

\subsection{Effect of Transfer Funds On Fiscal Independence}

Sig value. path $\mathrm{X} 2$ to $\mathrm{Y}(\mathrm{P} 2)$ of 0.000 is smaller than the alpha value of 0.05 . This means that transfer funds have an effect on fiscal independence. Thus, the second hypothesis which states that transfer funds have an effect on fiscal independence, is acceptable.

\subsection{The Effect of Pad on Capital Expenditure}

Sig value. path $\mathrm{X} 1$ to $\mathrm{Z}(\mathrm{P} 3)$ of 0.906 is greater than the alpha value of 0.05 . This means that local revenue has no effect on capital expenditure. Thus, the third hypothesis which states that PAD has an effect on capital spending is rejected.

\subsection{Effect of Transfer Funds on Capital Expenditures}

Sig value. path $\mathrm{X} 2$ to $\mathrm{Z}(\mathrm{P} 4)$ is 0.174 greater than the alpha value of 0.05 . This means that transfer funds have no effect on capital expenditure. Thus, the fourth hypothesis which states that transfer funds have an effect on capital spending is rejected.

\subsection{The Effect of Capital Spending On Fiscal Independence}

Sig value. path $\mathrm{Z}$ to $\mathrm{Y}$ (P5) of 0.332 is greater than the alpha value of 0.05 . This means that capital expenditure has no effect on fiscal independence. Thus, the fifth hypothesis which states that capital spending affects fiscal independence is rejected.

\subsection{The Effect of Pad on Fiscal Independence Through Capital Spending}

Sig value. path $\mathrm{X} 1$ to $\mathrm{Z}(\mathrm{P} 3)$ of 0.906 is greater than the alpha value of 0.05 . This means that local revenue has no effect on capital expenditure. While the value of sig. path $\mathrm{Z}$ to $\mathrm{Y}$ (P5) of 0.332 is greater than the alpha value of 0.05 . This means that capital expenditure has no effect on fiscal independence. Thus, the sixth hypothesis which states that PAD affects fiscal independence through capital expenditures is rejected.

\subsection{Effect of Transfer Funds on Fiscal Independence Through Capital Spending}

Sig value. path $\mathrm{X} 2$ to $\mathrm{Z}(\mathrm{P} 4)$ is 0.174 greater than the alpha value of 0.05 . This means that transfer funds have no effect on capital expenditure. Meanwhile, sig. path Z to $\mathrm{Y}$ (P5) of 0.332 is greater than the alpha value of 0.05 . This means that capital expenditure has no effect 
on fiscal independence. Thus, the seventh hypothesis which states that transfer funds have an effect on fiscal independence through capital expenditures is rejected.

\section{CONCLUSIONS}

The results of the analysis prove that, first, local revenue has an effect on fiscal independence. Thus the first hypothesis can be accepted. Second, the transfer funds have an effect on fiscal independence. Thus the second hypothesis can be accepted. Third, local revenue has no effect on capital spending. Thus the third hypothesis is rejected. Fourth, the results of the analysis also prove that transfer funds have no effect on capital spending. Thus the fourth hypothesis is rejected. Fifth, capital spending has no effect on fiscal independence. Thus the fifth hypothesis is rejected.

The next conclusion in this study is the Regional Original Income (PAD) and Transfer Funds have a direct effect on Fiscal Independence. This is because the regression coefficient value between the PAD variable and direct fiscal independence is greater than the regression coefficient value between the PAD variable on fiscal independence through capital spending. In addition, the regression coefficient value between the variable transfer funds on fiscal independence is directly greater than the regression coefficient value between the variable transfer funds on fiscal independence through capital expenditure. So it can be said that this research model is not suitable for the capital expenditure variable as an intervening variable.

\section{REFERENCES}

[1]. Aisyah, Siti. 2019. Pengaruh Pendapatan Asli Daerah, Dana Alokasi Umum Dan Dana

Alokasi Khusus Terhadap Tingkat

Kemandirian Keuangan Daerah Kabupaten

Sumbawa Periode Tahun Anggaran 2012-2018. (Online),

(https://scholar.google.co.id/), di akses 25 Oktober 2019

[2]. Ariani, K. R. \& Putri, G. A. 2016. Pengaruh Belanja Modal Dan Dana Alokasi Umum Terhadap Tingkat Kemandirian Keuangan Daerah. Jurnal Akuntansi Syariah, (Online), 364-369, (https://scholar.google.co.id/), di akses 18 Oktober 2019

[3]. Chabibillah, Ahmad. 2019. Analisis Pengaruh Dana Alokasi Umum, Dana Alokasi Khusus, Dana Bagi Hasil, Dan Belanja Modal Terhadap Tingkat Kemandirian Keuangan Daerah (Studi Empiris Pada Kabupaten/Kota Di Provinsi Jawa Tengah Tahun 2014-2016). Naskah Publikasi
Akuntansi. (Online),

(https://scholar.google.co.id/), di akses 28 November 2019

[4]. Fadillah R, R. A. N. 2018. Analisis FaktorFaktor Yang Berpengaruh Terhadap Belanja Modal (Studi Kasus Pada Pemerintah Kabupaten/Kota Di Jawa Tengah Tahun 2015 2016). Naskah Publikasi Akuntansi, (Online),(https://scholar.google.co.id/), di akses 28 November 2019.

[5]. Firdausy, C., M. 2018. Kebijakan dan Strategi Peningkatan Pendapatan Asli Daerah dalam Pembangunan Nasional. (Online). (https://books.google.co. id). Di akses 10 November 2019

[6]. Ghozali, Imam. 2011. Aplikasi Analisis Multivariate Dengan Program SPSS. Semarang: Badan Penerbit Universitas Diponegoro.

[7]. Halim, Abdul. 2007. Akuntansi Sektor Publik: Akuntansi Keuangan Daerah (Edisi 3). Jakarta: Salemba Empat.

[8]. Halim, Abdul. 2016. Manajemen Keuangan Sektor Publik (Edisi 2). Jakarta: Salemba Empat.

[9]. Irvan, I Putu \& Karmini, Ni Luh. 2016. Pengaruh Pendapatan Asli Daerah, Dana Perimbangan Terhadap Pertumbuhan

Ekonomi Dengan Belanja Modal Sebagai Variabel Intervening. Jurnal Ekonomi Pembangunan, (Online), 5 (3): 338-362, (https://scholar.google.co.id/), di akses 18 Oktober 2019

[10]. Jariyah, Ainun. 2014. Pengaruh Pertumbuhan Ekonomi, Dana Alokasi Umum, Pendapatan Asli Daerah, Sisa Lebih Pembiayaan Anggaran, Dan Luas Wilayah Terhadap Belanja Modal (Studi Empiris Pada Kabupaten/Kota Se Jawa Tengah). Naskah Publikasi Akuntansi, (Online), (https://scholar.google.co.id/) , di akses 28 November 2019

[11]. Kementerian Keuangan Republik Indonesia. Dana Alokasi Umum. (Online). (http://www.djpk.kemenkeu.go.id/). Di akses 06 November 2019.

[12]. Kementerian Keuangan Republik Indonesia. Dana Bagi Hasil. (Online). (http://www.djpk.kemenkeu.go.id/). Di akses 06 November 2019 
[13]. Kementerian Keuangan Republik Indonesia. Deskripsi dan Analisis APBD 2011. (Online). (http://www.djpk.kemenkeu.go.id/). Di akses 09 November 2019

[14]. Kementerian Keuangan Republik Indonesia. Pajak Daerah. (Online). (http://www.djpk.kemenkeu.go.id/). Di akses 04 November 2019

[15]. Kementerian Keuangan Republik Indonesia. Retribusi Daerah. (Online). (http://www.djpk.kemenkeu.go.id/). Di akses 04 November 2019.

[16]. Kementerian Keuangan Republik Indonesia: Direktorat Jenderal Perimbangan Keuangan. 2017. Ringkasan Anggaran Pendapatan dan Belanja Daerah. (Online). (http://www.djpk.kemenkeu.go.id/). Di akses $18 \quad$ November 2019.

[17]. Khairul, Muluk, M. R. 2009. Peta Konsep Desentralisasi \& Pemerintahan Daerah. (Online). (https://books.google.co.id). Di akses 06 November 2019.

[18]. Khusaini, Moch. 2018. Keuangan Daerah. Malang: Universitas Brawijaya Press.

[19]. Kiak, Novi, Theresia \& Nuro, Septina. 2018. Pengaruh Pendapatan Asli Daerah, Dana Alokasi Umum Dan Dana Alokasi Khusus Terhadap Tingkat Kemandirian

Keuangan Daerah Pada Kabupaten Banyuwangi Tahun 2012-2016. Jurnal Ekonomi, (Online), (https://scholar.google.co.id/), di akses 18 Oktober 2019.

[20]. Kosim, Engkos. 2017. Pengaruh Pendapatan Asli Daerah (PAD), Dana Alokasi Umum (DAU), Dan Sisa Lebih Pembiayaan Anggaran (SiLPA) Terhadap Anggaran Belanja Modal Pada Pemerintah Kota Banjar. Jurnal Manajemen, (Online), 1 (1):13-23, (https://scholar.google.co.id/), di akses 21 Oktober 2019.

[21]. Lestari, A., Dali, N., \& Abdullah, M. 2016. Pengaruh Dana Alokasi Umum (DAU) Dan Pendapatan Asli Daerah (PAD) Terhadap Belanja Modal Dan Kemandirian Keuangan Daerah Provinsi Sulawesi Tenggara. Jurnal Progres Ekonomi Pembangunan, (Online), 1 (2): 44-55, (https://scholar.google.co.id/), di akses 18 Oktober 2019.
[22]. Mahmudi. 2010. Manajemen Keuangan Daerah. Yogyakarta: Erlangga.

[23]. Nasution, A. P., Handoko, B., \& Pohan, I. R. A. 2018. Analisis Pengaruh Pendapatan Asli Daerah, Transfer Pemerintah Pusat Dan Efisiensi Belanja Daerah Terhadap Kemandirian Keuangan Daerah Kabupaten/Kota Di Provinsi Sumatera Utara. Jurnal Akuntansi Bisnis dan Publik, (Online), 9 (1):192-206, (https://scholar.google.co.id/) , di akses 25 Oktober 2019.

[24]. Novalistia, R. L. 2016. Pengaruh Pajak Daerah, Retribusi Daerah, Lain-Lain Pendapatan Asli Daerah Yang Sah Dan Bagi Hasil Pajak Terhadap Tingkat Kemandirian Keuangan Daerah Pada Pemerintahan Kabupaten Atau Kota Di Provinsi Jawa Tengah. Jurnal Akuntansi, (Online), 2 (2), (https://scholar.google.co.id/), di akses 25 Oktober 2019.

[25]. Orocomna, M. Bharanti, B. E., \& Layuk, P. K. A. 2017. Faktor-Faktor Yang Mempengaruhi Kemandirian Daerah Kabupaten Teluk Bintuni Tahun 2010-2015. Jurnal Kajian Ekonomi Dan Keuangan Daerah. (Online), 2 (3), (https://scholar.google.co.id/), di akses 28 November 2019.

[26]. Peraturan Menteri Keuangan Republik Indonesia Menimbang Nomor 48/Pmk.07/2019 Tentang Pengelolaan Dana Alokasi Khusus Nonfisik.

[27]. Peraturan Pemerintah Republik Indonesia Nomor 12 Tahun 2019 Tentang Pengelolaan Keuangan Daerah.

[28]. Peraturan Presiden Republik Indonesia Nomor 141 Tahun 2018 Tentang Petunjuk Teknis Dana Alokasi Khusus Fisik Tahun Anggaran 2019 Undang-Undang Republik Indonesia Nomor 28 Tahun 2009 Tentang Pajak Daerah Dan Retribusi Daerah.

[29]. Prastiwi, A., Nurlaela, S., \& Chomsatu, Y. 2016. Pengaruh Pendapatan Asli Daerah, Dana Perimbangan, Dan Belanja Pegawai Terhadap Belanja Modal Pemerintah Kota Surakarta. (Online), 872-879, (https://scholar.google.co.id/), di akses 28 November 2019.

[30]. Purnima, D., Saleh, C., \& Noor, I. 2015. Pengaruh Dana Bagi Hasil, Dana Alokasi Umum, Dan Dana Alokasi Khusus Terhadap Kemandirian Fiskal Dengan Desentralisasi Fiskal Sebagai Variabel 
Moderating Di Kabupaten Dan Kota Provinsi Jawa Timur. Jurnal Ilmu Administrasi Publik (JAP), (Online), 3 (6): 969-975, (https://scholar.google.co.id/), di akses 22 Oktober 2019.

[31]. Sari, N., Djuanda, G., \& Sarwani. 2018. Pengaruh Dana Perimbangan, Dana Sisa Lebih Perhitungan Anggaran (Silpa) Dan Pendapatan Asli Daerah Terhadap Belanja Modal Dan Dampaknya Pada Pertumbuhan Ekonomi. Jurnal Riset Manajemen dan Bisnis (JRMB), (Online), 3 (1): 91-100, (https://scholar.google.co.id/), di akses 28 November 2019.

[32]. Sarwoko, Endi. 2018. Buku Ajar Metodologi Penelitian. Malang: Universitas Kanjuruhan Malang.

[33]. Sarwono, Jonathan. 2011. Mengenal Path Analysis: Sejarah, Pengertian dan Aplikasi. (Online). 11 (2): 285- 296, (https://ejournal.ukrida.ac.id), di akses 09 November 2019.

[34]. Siregar, Baldric. 2015. Akuntansi Sektor Publik (Akuntansi Keuangan Pemerintah Daerah Berbasis Akrual). Yogyakarta: Sekolah Tinggi Ilmu Manajemen YKPN.

[35]. Undang-Undang Republik Indonesia Nomor 9 Tahun 2015 Tentang Perubahan Kedua Atas Undang-Undang Nomor 23 Tahun 2014 Tentang Pemerintahan Daerah.

[36]. Undang-Undang Republik Indonesia Nomor 23 Tahun 2014 Tentang Pemerintahan Daerah.

[37]. Undang-Undang Republik Indonesia Nomor 33 Tahun 2004 Tentang Perimbangan Keuangan Antara Pemerintah Pusat dan Pemerintah Daerah.

[38]. Yamin Sofyan, Kurniawan Heri. 2009. SPSS COMPLETE: Tekhnik Analisis Statistik Terlengkap dengan software SPSS. Jakarta: Salemba Infotek.

[39]. Yuliani, Irma. 2019. Pengaruh Belanja dan Investasi Terhadap Kemandirian Dan Pertumbuhan Ekonomi Daerah. (Online). (https://books.google.co.id) Di akses 09 November 2019.

[40]. Yulianto, Andri. 2018. Analisis Pengaruh Pendapatan Asli Daerah, Dana Alokasi Umum, Dana Alokasi Khusus,Dan
Belanja Modal Terhadap Tingkat Kemandirian Keuangan Daerah (Studi Empiris Pada Kabupaten/Kota di Provinsi Jawa Timur Tahun 2014-2016). Naskah Publikasi Akuntansi, (Online), (https://scholar.google.co.id/), di akses 25 Oktober 2019. 